\title{
NARRATIVAS DE NOSSO TEMPO: NOTAS SOBRE A CANÇÃO POPULAR COMO EXPERIÊNCIA DE FORMACุÃO
}

\author{
Julia Pinheiro Andrade*
}

RESUMO: Este trabalho desenvolve uma reflexão sobre figuras recentes da modernidade cultural brasileira, de modo a evidenciar o sentido formativo que a experiência estética pode assumir no campo da educação. Discutem-se a forma da canção brasileira e as especificidades de cancionistas que elaboram uma experiência da cidade de São Paulo, explorando a canção como forma narrativa. A pesquisa constela imagens da cidade em momentos críticos de seu desenvolvimento e reflete sobre as diferentes experiências estéticas como experiências de formação (especialmente significativas para os jovens). Consideramos, assim, a canção como um rito cotidiano com o poder de afirmar e negar o sujeito na cultura tensa e contra-ditória da metrópole, na medida em que a decanta como experiência.

Palavras-chave: Canção; Música Popular Brasileira; Educação; Experiência Estética; Modernidade

\section{NARRATIVES OF OUR TIME:}

NOTES ON POPULAR SONGS AS AN EDUCATIONAL EXPERIENCE

ABSTRACT: This work develops a reflection on recent figures of the Brazilian cultural modernity to remark the formative sense that the aesthetic experience can take in education. Specifically, it discusses the Brazilian song form and the specificities of songsters that elaborate an aesthetic experience from São Paulo City by exploring the song as a narrative form. The research depicts critical moments of the city development, and ponders on different aesthetic experiences as formative experiences especially significant for the young. The popular song is a hybrid form (music and literature) that allows a connection between individual experiences and a possibility of a collective communicative experience (of a generation), essential for the youngsters' affirmative condition in the contemporary society. Thus, songs are considered as daily rites with the power to confirm or deny the subject in the tense and contradictory metropolitan culture as it decants (and praises) urban experience.

Keywords: Song; Brazilian Popular Music; Education; Aesthetic Experience; Modernity

\footnotetext{
* Mestre em educação pela Universidade de São Paulo (USP) e Professora da Escola Castanheiras..E-mail: juliapa@uol.com.br
} 


\section{CULTURA CALEIDOSCÓPICA, EXPERIÊNCIA ESTÉTICA E CANC̦ÃO}

O poder da música é grande. Com o avanço tecnológico e a massificação da cultura, tornou-se ainda maior, penetrando todos os espaços da vida cotidiana. Pensar sobre esse poder é pensar sobre a cultura contemporânea, cuja massificação tem transformado a própria estrutura da percepção e do conhecimento. Para a educação, essa mutação é de suma importância, pois acarreta o que Michel De Certeau (2005, p. 112) nomeou de cultura estudantil caleidoscópica. Por assimilar a rapidez e a fragmentação das linguagens massificadas das mídias, a cultura jovem torna-se uma miscelânea de referências diversas, muito pouco diferenciadas e hierarquizadas. Diante dessa mutação cultural, o conhecimento escolar (sobretudo no ensino médio e no universitário) está muitas vezes defasado e impotente. Não tem o poder de organizar ou "juntar" os cacos da mídia e da cultura, mas justapõe-se e nivela-se a eles. O saber escolar "não diz a última palavra sobre a cultura de massa; ele tem a mesma forma que ela" (DE CERTEAU, 2005, p. 112). Daí o autor apontar para o fato de que a massificação e a democratização do ensino, em todos os seus níveis, "indica à cultura sua própria definição, ao remeter o saber estabelecido a uma prática do pensamento, e os objetos conceituais que ela veicula aos sujeitos que a produzem" (DE CERTEAU, 2005, p. 106).

Lidar com a cultura caleidoscópica é forçar a inteligência a um confronto prático com as linguagens culturais que a informam, problematizando-as. É forjar um sentido formativo no interior do acúmulo de informações, processando sínteses, fisionomias, relações e pontos de vista capazes de organizar juízos, posições, discursos e práticas. As várias formas de educação defrontam-se, portanto, com a tarefa de reinventar as promessas críticas do conhecimento iluminista, o qual pressupunha um indivíduo autônomo, centrado e esclarecido que, hoje, praticamente desapareceu na multidão de anônimos apressados das metrópoles. Como afirma De Certeau, é preciso remeter o saber às práticas do pensamento e aos objetos culturais veiculados aos sujeitos que produzem e são produzidos pela cultura do presente. Sem essa remissão às práticas, os saberes, as habilidades, os valores, em uma palavra, a cultura que se quer preservar pela educação, se tornam uma abstração desconexa, um sólido que se esfuma no ar. O interesse do estudo da canção na educação é, portanto, o interesse por uma linguagem da cultura especialmente forte no Brasil e que diz muito sobre os tempos e as formas de sociabilidade nas cidades contemporâneas, sobretudo no que diz respeito aos circuitos e às culturas 
jovens ${ }^{1}$. Seu estudo pode permitir a imaginação criativa de estratégias e táticas que reinventem um projeto moderno de educação.

Em termos sociológicos e históricos, pode-se sustentar que a canção é uma linguagem constituinte e enunciadora de uma desejável e necessária "educação da sensibilidade", tão ou mais importante na formação do jovem do que as artes plásticas e a literatura, cuja importância na formação escolar (e fora dela) é, hoje, inequívoca, e seu espaço, bastante assegurado ${ }^{2}$. Difere-se, no entanto, por não provir dos paradigmas "universais" da escrita e da cultura letrada (incorporadas do "espelho civilizatório" europeu), uma vez que toda a música brasileira provém da oralidade, do corpo e da miscigenação entre africanos, índios, europeus, sertanejos, mamelucos, cafuzos e mulatos - uma complexa mistura que deita longas raízes na sociabilidade escravocrata. Ademais, diferentemente do estatuto secundário que a canção assume na hierarquia das linguagens culturais na escola, a literatura e as artes plásticas já estão, há séculos, incorporadas ao cânone da cultura ocidental, condição que as naturaliza como linguagens importantes e distintivas. Apenas muito recentemente a canção passa a ser reivindicada como uma forma autônoma e uma tradição artística potente de criação estética, produto e produtora de narrativas e instituições simbólicas do imaginário contemporâneo.

A razão disso é histórica. O movimento de emancipação formal da canção é um processo moderno eminentemente urbano-comercial, transcorrido sob forte condicionamento dos processos de modernização sofridos pelas grandes cidades. Ao contrário do que ocorre em manifestações tradicionais do folclore e de ritos comunitários, a força narrativa da canção urbana moderna está entranhada na gênese mesma das tensões de sua forma, que, por assim dizer, "decanta" a consolidação das principais vertentes da indústria cultural (sistema de comunicação de massas impressa, radiofônica e televisiva). Isso significa que se trata de uma forma viva, específica da linguagem musical recente (consolidada no entreguerras dos anos 1920-30), cuja mistura entre erudito e popular, entre literatura e música, entre arte e entretenimento, variou imensamente em cada formação cultural em função das articulações específicas entre as tradições e as engrenagens das indústrias culturais de cada país. Embora as músicas nacionais tenham desenvolvido formas singulares, mais ou menos derivadas das artes tradicionais (urbanas ou rurais pré-industriais), a moderna canção torna-se uma forma narrativa e um fator ativo de elaboração cultural especialmente forte nas culturas britânica, norte-americana e brasileira $^{3}$. Nessas formações, a canção se emancipa do folclore, se urba- 
niza, se industrializa, se sofistica tecnicamente, mantendo ainda certos aspectos artesanais, e se afirma ao longo do século XX em relação tensa com os vários níveis do cânone artístico (tanto em relação às tradições de gêneros nacionais tidos como "clássicos", quanto em relação às tendências de vanguarda, que talham espaço para o novo) (Cf. WISNIK,1983).

É nesse contexto que, no presente trabalho, são pensadas as "formas vivas" que falam e cantam a cidade, revelando o urbano de um ângulo rico e insuspeito - experiência estética e educação. Trata-se de uma reflexão sobre a correspondência entre a forma estética da canção e a experiência urbana na cidade de São Paulo, cidade-índice da experiência brasileira e, portanto, aberta a conexões também mundiais. Nesse compasso, procura-se evidenciar a força da linguagem da canção no Brasil e demonstrar a fecundidade da escuta analítica de canções como formação, isto é, como forma de sentir, de pensar e de realizar uma crítica da cultura contemporânea.

A experiência estética da cidade expressa, elabora e ensina formas de viver, perceber e conceber espaços e tempos de liberdade face às complexas figuras da modernidade e da modernização urbanas. A forma estética constrói subjetividades e informa sobre o mundo, pois tem o poder de revelar outra realidade na realidade, de propor outro mundo no mundo, transformando vivências individuais em experiência partilhável entre muitos, transfigurando os limites do real em poder de narrá-lo e projetá-lo pela imaginação. A experiência estética abre, assim, outra maneira de se pensar a educação, uma maneira não totalizadora, nem diretiva, mas justamente aberta ao indeterminado, ao possível e ao múltiplo.

É certo que, ao lado da experiência de fruição de obras, a análise estética organiza procedimentos, propõe relações, demonstra aspectos, sistematiza conhecimento e saber. Mas, ao contrário do saber escolar sistematizado, o sentido da experiência estética não pode ser jamais reduzido à análise e à instrução. Apesar da objetividade da obra, há algo de irredutível e único em cada fruição, em cada performance, em cada momento de recepção, tanto no que diz respeito à dimensão subjetiva e pessoal de quem a experimenta, quanto na dimensão histórica e social em que a obra se situa e ganha significados. É assim que, por correspondência, as linguagens artísticas têm se tornado uma forma potente e crítica para se elaborar a vida urbana contemporânea, um modo de apreender e narrar seus conflitos, paradoxos e indeterminações. 


\section{A CANÇÃO NO BRASIL}

A canção no Brasil se tornou, ao mesmo tempo, o mais cotidiano dos objetos de consumo artístico-culturais de massa e uma forma estética expressiva, forte e autônoma de elaboração cultural. Como uma "enciclopédia implícita" da vida cotidiana (RODRIGUES, 1980 apud FAVARETTO, 2000, p. 145), reitera sofrimentos, alegrias, malandragens, safadezas; presentifica o imaginário da festa; repensa o destino e expõe contradições sociais. Embora manifestação complexa, sua base é uma só: a elaboração de pulsações dos ritmos e das linguagens do corpo, fazendose, então, como uma "rede de recados" de que "o conceitual é apenas um momento: o da subida à superfície" (WISNIK, 2004a, p. 170).

Aos olhos de um estrangeiro, isso pode vir a parecer um dos tantos paradoxos que configuram a sociabilidade e a cultura brasileiras, uma vez que em nenhuma outra parte do planeta a música popular e, dentro dela, a forma canção pode assumir tal complexidade, tão vasta em manifestações quanto em entrecruzamentos entre erudito e popular, literatura e cultura oral, sofisticação técnica e circulação de massa, forma estética singular e fórmulas de entretenimento em série. Por isso mesmo, a considerar, sobretudo, seu desenvolvimento moderno no século XX, a canção se tornou uma forma privilegiada de narração da experiência brasileira. A codificação específica de sua linguagem híbrida ${ }^{4}$, composta pelas dimensões da letra, da melodia, da harmonia, do arranjo e da performance, permitiu à canção conectar subjetividades individuais e coletivas e assumir rápida e facilmente uma dimensão social.

Nesse sentido, pode-se dizer que a canção é uma forma emblemática da cultura devido à especificidade de sua enunciação: expressa uma voz que simultaneamente fala e canta e, assim, ao mesmo tempo, partilha mensagens e libera índices, signos, significados e significâncias variados, que vinculam o individual ao coletivo. Inclusive e porque, desde muito cedo (nos 1920-30), foi moldada por setores da indústria cultural de alto poder de modernização (a indústria fonográfica, o sistema radiofônico e a imprensa de massas, posteriormente re-significados pela onipresente penetração da produção e circulação de imagens, com a televisão) (Cf. MAMMÍ, 1996; WISNIK, 1983). A moderna canção brasileira tornou-se ainda exemplar, portanto, da difusão social de costumes, comportamentos e valores culturais justamente ao realizar-se como forma mercadoria, isto é, realizando também um valor de troca necessariamente destinado ao consumo ${ }^{5}$. 
No Brasil, há uma infinidade de tipos de canções para o pé, para a cabeça, para o coração ${ }^{6}$ e para o corpo inteiro a modular e contrapor quase tudo o que se aprende sobre os próprios sentimentos, expressões corporais, pensamentos, desejos. A música, e especialmente a canção, se tornou uma vivência quase contínua na vida dos brasileiros, sobretudo entre os jovens. Juventude e canção foram se tornando um par quase indissociável, uma ajudando a produzir, a criar, a identificar e a consumir a outra. Como numa relação de espelhamento, o papel da canção na formação da subjetividade, da sociabilidade "típica" das "culturas juvenis" e da cultura brasileira de modo geral tem sido imenso. Entre as várias gerações e segundo a relação tensa entre arte e mercado, os sons e ruídos surgidos na terra ou assimilados do estrangeiro foram se mesclando e dando origem ao lundu, ao maxixe, à modinha, ao choro, ao samba, ao afoxé, ao maracatu, à bossa nova, à jovem guarda, ao tropicalismo e a todas as combinações e variações "pop" daí decorrentes. Tudo isso mais ou menos ao longo de um século de criações e hibridismos. Assim, à medida que chegava ao fim o século XX, chamado pelo músico e semioticista Luiz Tatit de o "século da canção", cresceu significativamente o número de ensaios e trabalhos acadêmicos das mais diversas áreas que tomam a canção popular brasileira como objeto de estudo e crítica (Cf. TERESA, 2004; BAIA, 2005).

José Miguel Wisnik evidenciou que as canções populares conseguiram forjar uma rede bastante singular de recados e de diálogos entre compositores, intérpretes, escritores, poetas e figuras da vida pública. Essa maneira de sinalizar a vida cultural do país formou quase um protoespaço público, configurando uma espécie de repertório comum de experiências sociais e estéticas ao transportar conhecimentos e linguagens entre as diferentes classes e circuitos culturais. Daí o autor sustentar que, mais do que uma forma viva de expressão, a linguagem da canção popular constitui-se como "uma nova forma de 'Gaia Ciência', isto é, um saber poéticomusical que implica uma refinada educação sentimental - mas, também, uma 'segunda e mais perigosa inocência na alegria" (WISNIK, 2004b, p. 218). A canção, assumindo, a um tempo, diferentes ethos e pathos, codifica pulsões da cultura de modo a potencializar as referências assumidas como matéria melódica. Assim, as canções se evidenciam como "matéria de uma experiência de profundas conseqüências na vida cultural brasileira nas últimas décadas" (WISNIK, 2004b, p. 218).

A música popular brasileira, dinamizada pelos meios técnicos do rádio e das gravadoras (sistema fonográfico) e, depois, da televisão, pro- 
moveu ao menos três grandes operações estéticas no século XX: 1) A consolidação do samba, nos anos 1920-30, do qual saíram muitas implicações musicais e ideológicas para a vida cultural nacional ${ }^{7}$; 2) O surgimento da bossa nova, no final dos anos 1950, a operar uma triagem na "voz da fala" e na "fala da voz" (TATIT, 2004; BARTHES, 2004) da música brasileira e a realizar uma apropriação do cool jaž e do samba (GARCIA, 1999), de modo a alcançar um resultado definidor de nossa Moderna MPB; 3) O acontecimento turbilhonante do tropicalismo, no final dos anos 1960, que realizou a autonomia formal da canção, ao liberála para processar a mistura da MMPB com o pop internacional das guitarras, com a incorporação de happenigs e a desconstrução do objeto artístico operada como um ready-made, com citações da literatura brasileira, com a poesia concreta, com o cinema novo, com a recuperação da música "cafona" pré-bossa nova, pondo tudo isso no cadinho de uma operação antropofágica muito própria (FAVARETTTO, 2000b).

A produção, a circulação e o amplo consumo social e cultural da canção no século XX tornaram evidente e mesmo consensual na cultura mundial a relevância dessa experiência condensada esteticamente. Ou melhor, dessa experiência social decantada em música. E isso não é um feito qualquer para um país cuja difícil formação, no final do mesmo século $\mathrm{XX}$, dava indícios de que "o desenvolvimento nacional pode não ter sido nem desenvolvimento, nem nacional” (SCHWARZ, 1999, p. 158).

\section{SÃO PAULO: CIDADE CANTADA}

Para lidar com esse conjunto de tensões da modernidade cultural brasileira, nada melhor do que a consideração de canções sobre São Paulo, cidade ícone do desenvolvimento e da crise nacional, onde todas as tendências se encontram e entrecruzam num melting pot cultural. A partir de mais ou menos 1950, São Paulo se tornou, com efeito, o símbolo nacional da mistura de população e da aceleração de processos de modernização em escala metropolitana, fato que a música popular urbana expressa e revela nas especificidades de sua linguagem. Embora seja arriscado, é possível pensar em uma arcada estético-histórica do que Wisnik (2004c) chamou de "música popular paulista": uma mistura de gêneros e estilos musicais composta tanto por paulistas de nascimento quanto por migrantes de toda cor e matiz. Entre outros que compuseram sobre e a partir das vivências urbanas de São Paulo, podemos citar 
Geraldo Filme, Adoniran Barbosa, Premeditando o Breque, Grupo Rumo, Luiz Tatit, Rita Lee, Os Mutantes, Billy Blanco, Paulo Vanzolini, Tom Zé, Arnaldo Antunes, Titãs, Eduardo Gudin, Ultraje a Rigor, José Miguel Wisnik, Arrigo Barnabé, Itamar Assumpção, Mamonas Assassinas, Racionais MC's, Thaíde e DJ Hum, Sabotage e Rappin'Hood.

Como os braços que ergueram a cidade moderna, muitas das canções sobre São Paulo foram feitas por migrantes ou filhos de migrantes que apenas no espaço cosmopolita e modernizante da metrópole puderam lançar-se ao sucesso. Lugar de desenraizamento, de risco, mas também de grandes oportunidades, esses costumam ser atributos associados à imagem de São Paulo, assustando e atraindo o forasteiro. A canção sobre a cidade figura essas características de inúmeras maneiras.

Por ocasião dos 450 anos da cidade, em 2004, o telejornal SPTV, da Rede Globo, organizou um concurso para eleger a música que melhor a representasse. As ganhadoras foram composições de "forasteiros" completamente assimilados pelo imaginário afetivo da cidade e que, em São Paulo, tornaram-se nomes importantes da música brasileira: em primeiro lugar, Trem das onze (1964), de Adoniran Barbosa (nascido como João Rubinato em Valinhos, crescido entre Jundiaí e Santo André, todas elas cidades do interior de estado de São Paulo, amadurecido como saltimbanco entre mil empregos e biscates, mas autotransformado no artistapersonagem Adoniran Barbosa nas rádios de São Paulo); em segundo lugar, Sampa (1978), de Caetano Veloso (nascido em Santo Amaro da Purificação, no estado da Bahia, mas tornado nacionalmente conhecido desde os anos 1960 por meio dos festivais da canção de São Paulo, de que se lançou para uma carreira de sucesso internacional e ímpar entre os músicos brasileiros). Ao analisar o fato, o jornalista e escritor Roberto Pompeu de Toledo notou que, embora em dicções muito distintas, ambas as canções codificam o signo do movimento, da mudança, do estranhamento e da aceleração como características fundamentais da cidade, sem que, no entanto, os narradores deixem de encarnar "eus-líricos" profundamente embebidos por ela:

(...) Em Sampa a perturbação que o compositor sente diante de São Paulo tem uma contrapartida - a atração. Tanto quanto estranheza, a letra sugere um caso de sedução pelo grande e o desconhecido, e pela promessa de enriquecimento neles contida. E que, em Trem das Onze, em paralelo ao drama, transcorre uma comédia, estrelada por um sujeito inseguro, perdido entre seus afetos e lealdades, incapaz de superar obstáculo tão comezinho quanto um horário de trem. Conclusão: São Paulo pode ser perturbadora como em 
Sampa e opressora como em Trem das Onze, mas também sedutora como em Sampa e divertida como em Trem das Onze. (TOLEDO, 2004, p. 19-20)

Ambas as canções têm também um traço acentuadamente narrativo, como que a recompor um sentido mais amplo a vivências isoladas e sem maiores enraizamentos na vida da cidade. $O$ fato de o "cidadão paulistano" (construído pela Rede Globo) as ter escolhido como "espelho" da cidade tem aí seus fundamentos históricos. Comentando traços de permanência nas transformações da canção "paulistana", o historiador José Geraldo Vinci de Moraes identifica uma linhagem de crônicas que atravessa quase todo o século XX, das modinhas recolhidas por Alcântara Machado, em 1920, às composições de Adoniran Barbosa e de Paulo Vanzolini (de certo modo, recuperadas por Caetano Veloso). Celebradas desde os anos de 1970 como "clássicos da cidade", cumpriram o papel simbólico de "eternizar", na memória coletiva, vivências melodramáticas e cômicas de encontros e desencontros típicos de "cidade grande". Isso se deu em um momento em que o imaginário rural do país começava a se dissolver com a urbanização acelerada e crescente, dando forma a uma nova "identidade" cultural que, então, passou a unir campo e cidade em um "todo urbano".

Parece mesmo que o tom marcadamente narrativo, personalizado, envolvendo temas no mais das vezes urbanos, acabou se tornando característico da música paulistana. Sua permanência, transformada, aponta para a formação de uma certa tradição da cultura urbana paulistana, originária da popular e oral, e pode nos aproximar daquilo que Florestan Fernandes denominou de modo genérico de "folclore urbano"s.

Dos anos 1950 para cá, porém, o urbano se metamorfoseou ainda mais, dando lugar a vivências mais intensas e difíceis de serem elaboradas como experiência coletiva: violência, desigualdade econômica, trânsito, desemprego, miséria urbana, esbanjamento, abandono, desperdício, competição, poluição sonora, visual e ambiental, enfim, um aparente caos metropolitano que, porém, pulsa segundo a lógica e o diapasão socioeconômico do desenvolvimento desigual e combinado do território (SANTOS, 1994; 1990).

A superação da barbárie objetiva em que vem se convertendo a vida em São Paulo - "cidade de muros" (CALDEIRA, 2000) - corresponde à passagem de vivências imediatas da crise urbana à elaboração de experiências da cidade, mediadas pela reflexão sobre a própria percepção 
dos processos urbanos 9 . Considerem-se, por um momento, três compositores importantes para São Paulo: Adoniran Barbosa e seu samba urbano de sotaque "ítalo-macarrônico", saído de bairros como o Brás e o Bexiga; Tom Zé, com seu olhar matuto de sertanejo baiano, escolado em vanguardismo europeu na Faculdade de Música da Universidade Federal da Bahia, a compor crônicas musicais sobre a cidade a partir de 1968, quando nela passa a viver; e o Racionais MC's, que decanta uma "etnografia épica" sobre as periferias paulistanas sob a forma de rap - "ritmo e poesia".

Para apenas enumerar temas, sem ainda considerar propriamente a forma das canções, pode-se indagar como a cidade de Adoniran Barbosa, em que se ia caminhando a festas na vizinhança ("No morro da casa verde", "Fica mais um pouco amor"), em que havia muita solidariedade e reciprocidade na vida das camadas mais pobres dos trabalhadores ("Vide verso meu endereço"), na qual a dor era lembrada em samba passional como forma de esquecimento e assimilação da perda, mas também de respeito pela "ordem superior" dos homens que "estão com a razão" ("Saudosa maloca", "Despejo na favela"); em que os temas do amor e da alegria eram amplamente cantados ("Tiro ao Álvaro", "Trem das onze", "Samba do Ernesto", "Vila Esperança"), apesar de acidentes, "apagões" e desencontros ("Iracema", "Apaga o fogo Mané", "Bom dia tristeza", "Luz da Light", "Acende o candieiro"), como essa cidade se transformou em algo cuja "mais completa tradução" passou a ser cantada apocalipticamente pela força bruta e "antimelódica" do rap do Racionais? Neste, além da fé (sincrética entre candomblé e cristã), o amor praticamente não é narrado, tampouco o vislumbre de um futuro de trabalho formal e de acesso legal a um desejado mundo de consumo. Assim, no rap, ganha força o pathos de revolta diante da falta de esperança por espaços de inclusão não-violenta aos "50 mil manos" de periferias que se espalharam por todo lugar ("Diário de um detento", "Periferia é periferia", "Capítulo 4, versículo 3"), formando territórios em que o "negro drama", a "vida loka" (do crime) e a morte ganham primeiro plano ("Tô ouvindo alguém me chamar", "Fórmula mágica da paz", "Rapaz comum").

Parte desse elo histórico foi cifrado por meio das complexas figuras de montagens cinematográfica, cênica e radiofônica expressas nas "descanções” de Tom Zé (ZÉ, 2003; ANDRADE, 2007), que, chegando a São Paulo em 1968, percebeu uma série de pontos cegos no projeto de modernização que a cidade provinciana, de moral católica e conservadora ("Namorinho de Portão"), queria adotar como up-to-date no avanço das 
"boas maneiras" de metrópole. A aceleração da economia desenvolvimentista (à base de crescimento endividado) passava a espacializar, de uma maneira nova, um lugar comum da história urbana paulistana: o lugar periférico dos pobres, dos migrantes, dos negros descendentes de escravo. Ao mesmo tempo, as grandes avenidas passavam a receber as "novas catedrais" da cidade: conjuntos empresariais para grandes "chefes de família", que, em nome da tradição, "aguardando o dia do juízo/por segurança foi-lhes ensinando/a juntar muito dólar/dólar, dólar na terra" ("Glória"). Era uma cidade que crescia, namorava e dormia junto com a indústria automobilística, cujo relógio passava a andar "apressado demais/correndo atrás de letras/juros e capitais" "Não buzine que estou paquerando") e, nesse ritmo, procurava assimilar o way of life sugerido por novas mercadorias, mesmo que para isso o sujeito entrasse no crediário da liquidação e saísse "quase liquidado" ("Sem entrada e sem mais nada"). Longe de representarem uma novidade, o trabalho informal e precário dos pobres (Camelô), bem como o luxo e a bonança do ladrão grande, diplomado e de gravata ("Profissão ladrão"), apenas ganhavam novos contornos urbanos.

A cidade, como metrópole, passava a ser então um parque industrial, não principalmente de indústrias, que, poluídas e poluentes, estavam sempre nas margens inundáveis dos rios Tietê, Pinheiros e Tamanduateí; tampouco a cidade do trabalho assalariado, da promessa de inclusão no mercado formal de trabalho, dos direitos sociais mínimos e da casa própria; mas o parque de diversões e ilusões movido pela promessa de consumo, em que "tem garotas propaganda/aeromoças e ternura no cartaz", onde o trabalhador fatigado sente que "basta olhar para a parede/que num instante minha alegria se refaz", pois o sorriso "já vem pronto e tabelado/é somente requentar/e usar/porque é made, made, made/made in Brazil'. Em contrapartida a essa sedução, no entanto, pagava-se o preço de anos de chumbo e do arrocho salarial que estava na base do desenvolvimentismo militar: "é um banco de sangue encadernado/já vem pronto e tabelado/é somente folhear/e usar/porque é made, made, made/made in Brazil" ("Parque industrial"). Segundo o achado de Caetano Veloso nos anos 1970, a metrópole, agora tentacular, seduzia e devorava "o povo oprimido nas filas, nas vilas, favelas" ("Sampa"). A despeito das promessas de felicidade da modernidade, portanto, a regra social na maior cidade do Brasil se celebrizava por ser, custasse o que custasse, a da "força da grana que ergue e destrói coisas belas" ("Sampa"). Resultado de contradições crescentes, no entanto, nos anos 1990, o rap e o movimento hip 
hop passaram a assumir uma dimensão que talvez confirme outra intuição de Caetano sobre "Sampa": ser um "possível novo quilombo de Zumbi".

Em pinceladas rápidas, são estas algumas poucas imagens da mudança acelerada que, de 1950 a 1990, fizeram o contexto socioespacial da cidade moderna se transformar em cidade global ${ }^{10}$, metrópole caótica "pós-moderna". Em uma verdadeira análise de canções, é claro, não importa considerar apenas a mudança nos temas cantados por aqueles que conseguem traduzir a experiência urbana em forma estética - desse modo, alargando-a a um espaço de alteridade democrática, em tese, a todos que os escutam. Antes mesmo do conteúdo épico ou alegórico cifrado nas letras, é preciso analisar a mudança no gênero, no pulso do ritmo, na entoação da melodia, na configuração da dicção característica de cada cancionista, na performance que criam e inserem no imaginário da cultura. É a definição desse complexo de signos e de significantes da canção que atua como mediação para interpretá-la como índice de "gaia ciência", o que, por sua vez, pode ser posto em correspondência com a dramaticidade da transformação no processo social. É, portanto, das estruturas das canções, de suas organizações tensivas profundas, que se torna necessário depreender as conexões estéticas com a experiência da cidade, desse acontecer entre as palavras e as coisas que escapa ao conceito, mas codifica-se em som, em ritmo, em melodia e em palavra cantada.

Da ampla rede de canções sobre a "paulicéia desvairada" , podese destacar dois momentos contrastantes: a "descanção" de Tom Zé, que parte da experiência tropicalista sobre a cidade de São Paulo (com o LP Tom Zé, Grande Liquidação, de 1968) e a radicaliza em um projeto estético ímpar, sempre renovado em pesquisas de linguagem sonora; e o rap do Racionais MC's, que transformou o "ritmo do gueto" norte-americano em lírica épica sobre o "negro drama" das periferias brasileiras (desde o álbum independente Sobrevivendo no Inferno, de 1997). Na análise de ambos, no entanto, os sambas-crônica de Adoniran Barbosa sobre a cidade se tornam contrapontos iluminadores e, portanto, índices das grandes viradas na experiência de modernização da cidade e das formas de linguagem necessárias para narrá-las. A escolha da tônica sobre Tom Zé e Racionais deve-se tanto às inovações que trazem à linguagem da canção quanto ao fato de a terem transformado em uma forma singular de narrar uma experiência da cidade. Analisá-los torna-se, portanto, uma maneira de figurar imagens da cidade em momentos críticos de seu desenvolvimento urbano moderno e, ao mesmo tempo, refletir sobre diferentes experiências estéticas (traduzidas em música) como experiências de formação. Isto 
é, suas canções funcionam como ritos cotidianos que afirmam e negam o sujeito na cultura tensa e contraditória da metrópole, ritos que formalizam diferentes performances que ainda apontam para uma atitude crítica, uma atitude de modernidade problemática e ainda possível, por isso mesmo singular e notável.

Uma vez que a experiência urbana que tomam por matéria e objeto estético é tensa e contraditória, por correspondência, a própria forma narrativa também deve sê-lo, sob pena de não expressar a cidade adequadamente. Assim, de modos diversos, Tom Zé e Racionais MC's tornam-se especialmente interessantes porque cantam de modo a evidenciar e a pressionar os limites formais da canção. Antes dos conteúdos cantados, é a contundência da forma estética inovadora que produz a eficácia da experiência de formação que decantam. É esse alcance da forma estética que precisa ser considerado em educação: a abertura de significações que exige atitude crítica, diálogo, conversação, posicionamento e participação política. A análise da forma mostra como Tom Zé e Racionais questionam o "senso musical comum" e as hierarquias artísticas do cânone cultural brasileiro e aponta para resultados de interesse geral: conexões com questões pertinentes à música e à experiência urbana contemporâneas em praticamente todo o mundo. A força de suas performances advém, assim, de sua capacidade de compatibilizar na forma estética técnicas musicais e gestos narrativos fortes, cuja densidade fala tanto às pulsões corporais $^{12}$ quanto informa certo conceito sobre o urbano: esclarecem e fazem sentir. Convocam: fazem falar, pensar, expressar, cantar e agir.

\section{ESCOLA, JUVENTUDE E CANÇÃO}

Na cultura cambiante contemporânea, no entanto, a escola ainda representa um espaço institucional de preservação de conhecimentos, de linguagens, de costumes e de disciplinamento do corpo. Como afirma Hannah Arendt, a educação escolar cumpre o indispensável papel conservador de garantir a introdução dos novos nos campos de tradições culturais que ainda nos definem como humanos, como povo, como nação (ARENDT, 2000). Sem conservação não pode haver critérios e valores para a manutenção de um mundo comum, coletivo, civil, civilizado, público. Esse é, com efeito, um paradoxo da escola e da educação modernas: destinam-se a preservar os meios necessários à sustentação de um mundo coletivo e político comum, por definição democrático e igualitário, mas, 
ao fazê-lo, reproduzem as desigualdades e assimetrias da sociedade, mantendo o status $q u o^{13}$. E, no entanto, em um país como o Brasil, apenas a educação pública parece ainda permitir que os fundamentais processos de socialização, de reciprocidade e elaboração de conflitos se realizem de forma pública, ou seja, por meio da razão, da experiência e da prática do diálogo. Antes da universalização democrática do acesso ao ensino (que correspondeu ao intenso processo de massificação desde os anos 1960) ${ }^{14}$, apenas a música e os espaços de sociabilidade das festas populares puderam desempenhar um papel dialógico no Brasil' ${ }^{15}$, um papel de gaia ciência fundamentalmente oral, embora ressoando "rede de recados" entre a literatura e a música (WISNIK, 2004b).

Conservação e conversação são, portanto, categorias pertinentes à escolarização no Brasil, embora a primeira tenha historicamente predominado e negado espaço à segunda: uma como projeto civilizador incorporado de ultramar; outra como tradição cultural distintiva e singular da formação social brasileira. A crise do projeto moderno e a necessidade de se pensar uma educação "pós-Bildung" talvez permita pensar, finalmente, em uma convergência entre conservação e conversação de cultura de forma que ambas possam fortalecer a cultura do Brasil e a cultura no Brasil.

A escuta crítica da canção implica uma reflexão sobre os espaços de liberdade e as formas de sociabilidade presentes na sociedade atual, sobretudo no que diz respeito às aspirações das juventudes ${ }^{16}$. A (re)fundação do espaço público de encontros e de produção de cultura numa cidade apartada como São Paulo exige, por sua vez, a atualização de uma atitude crítica de modernidade frente às tarefas renovadoras da educação. As resistências dos jovens à formação que aí está (seja, por um lado, aos valores e às formas disciplinares da educação, seja, por outro lado, à pressão social para que assumam as responsabilidades da vida adulta em um mundo altamente competitivo e dessolidarizado), essas resistências não podem mais ser vistas como uma "anomalia" ou um "desvio" em relação a um ideal de jovem, de aluno, de "correção" ou de "acerto" pedagógico dado e estabelecido a priori. Ao contrário, as práticas e as formas de sociabilidade juvenil intra e extra-escolares da atualidade (de sua linguagem corporal cheia de percings, tatuagens, bonés, gorros, colares, etc., à adesão a estilos musicais, a identificação com artistas de cinema, de TV, etc.) exigem serem lidas como uma legítima procura de auto-afirmação em um mundo no qual os adultos estão se desresponsabilizando pela ética, pelos valores públicos e coletivos ${ }^{17}$. Mais do que isso, as "culturas 
juvenis" devem ser lidas como "sintomas do tempo", como sinais de conflitos culturais entre gerações que justamente devem ser incorporados como matéria de reflexão e da ação educativa. Estas, por sua vez, precisam reinventar o sentido da formação escolar para os jovens e para a cultura do mundo contemporâneo, sem abrir mão das tradições fundamentais que cabe à educação conservar. Uma tarefa complexa, sem dúvida, pois, como já alertou Walter Benjamin, os documentos de cultura são também os documentos de barbárie, a depender do modo pelo qual se dá sua transmissão. Por isso mesmo, a reinvenção do moderno sentido da formação deve deparar-se com o desafio que lhe lança a história, desafio que parte de uma posição crítica no presente, um "tempo saturado de agoras": a cada época "é preciso arrancar a tradição ao conformismo, que quer apoderar-se dela” (BENJAMIN, 1996c, p. 229, 224).

Por diferentes meios, o experimentalismo de Tom Zé e o rap do Racionais MC’s expressam questões dessa ordem. Ao narrarem a cidade, falam e "informam" o imaginário jovem contemporâneo, permitindo que o compreendamos um pouco mais. De diferentes lugares sociais, interpelam seu presente, a ordem social e a ordem dos discursos de seu tempo, evidenciando contradições e forjando espaços de criação e formação de subjetividade. Realizam operações estéticas muito distintas, mas cuja significância converge em um ponto fundamental. Ambos os cancionistas, ao tornarem tenso o jogo entre fórmulas e formas musicais, expõem um aparente óbvio da cultura:

O grande sistema industrial-comercial contribui para a constituição de uma classe de idade adolescente em reação contra a sociedade adulta, mas ao mesmo tempo, ele integra esta classe de idade na ordem geral da sociedade. Tende a destruir as fontes selvagens da arte musical, ao mesmo tempo em que tende a captá-las, a fim de explorá-las. (...) Submetido a uma necessidade de renovação constante, ele tende, naturalmente, a apelar para todas as fontes de renovação, portanto, para as fontes de criação originais. Em certo sentido, o caráter particular no mercado da canção, que pode ser rapidamente saturado e desgastado, apela não só para o artifício, mas também, para arte (MORIN, 1973, p. 155).

As formas artísticas e as formas culturais em geral ("depravadas" ou não, como ajuíza Theodor Adorno) funcionam como fonte legitimada socialmente de modelos de comportamentos, de repertórios de atitudes, de gestos, de vocabulário, de vestimenta, enfim, de códigos de linguagem capazes de diferenciar grupos e afirmar suas identidades no conjunto maior da sociedade (COSTA, 2002). As linguagens artísticas e especial- 
mente a canção veiculada pelos vários circuitos das mídias são modelos de performances, isto é, de atitudes que vinculam um modo de subjetivação a dada inserção social. Paul Zumthor já mostrou que a palavra cantada, a vOz, o gesto projetam o corpo no espaço da performance. Esta opera, então, uma presença, uma situação existencial "cuja tonalidade engaja os corpos dos participantes" em um discurso que "ao mesmo tempo se faz narrativa e, pelo som da voz e o movimento do corpo, comentário dessa narrativa: narração e glosa" (ZUMTHOR, 2001, p. 147-148).

Como observou pioneiramente Edgar Morin, no sistema comercial-urbano de canções há um jogo entre a força selvagem da novidade musical e o apaziguamento que a forma comercial produz. Jogo que procura combinar o novo com o tradicional de forma a atender às expectativas de um suposto ouvinte mediano (nem o culto, cosmopolita ou técnico, nem o leigo ou excessivamente localista) e, assim, poder tirar proveito mercadológico em escala de massa do que emerge como estética inovadora.

Ora é a particularidade de todo sistema da cultura de massa, da indústria cultural e aqui mais especificamente das gravadoras, empresários, enfim, do comércio da canção, a particularidade de todo esse sistema é limitar a tendência dionisíaca, mas sem destruí-la - a qual se limitara a certos recitais de quebra-quebra -, a característica do sistema é sufocar a rebeldia latente - ou afundá-la em uma latência ainda mais profunda - eliminar de qualquer maneira todas as manifestações explosivas, mas integrar e explorar as contribuições musicais rebeldes. Em suma, o sistema de massa esforçou-se para integrar a genialidade musical do movimento em beneficio de seu dinamismo, desarmando o explosivo social (MORIN, 2001, p. 153).

Morin diagnostica que, na escala de massa, as forças integradoras se tornam sempre mais fortes do que as desintegradoras: "O iê-iê-iê é a aclimatização, a aculturação da força originalmente selvagem do rock" (MORIN, 1973, p. 154), pois sua corrosão concentrou-se mais na dimensão verbal do que musical da canção. Nesse sentido, pensando nas pulsões da sociedade de massas, Morin previu a necessidade do surgimento do punk-rock, do punk e do bard core (na década de 1970) e, posteriormente, do rap (na década de 1980), formas outsiders que surgem exatamente para contestar de modo virulento a música estabelecida e a sociedade de seu tempo:

O neofolclore, como o rock transmutado em twist, depois em ê-iê-iê, está integrado em sua genialidade musical, circunscrito e amordaçado pelo grande 
sistema industrial-comercial. Isto significa que uma outra força marginal, rebelde se manifestará novamente (MORIN, 1973, p. 155).

Esse desenvolvimento da canção, tensionada entre o novo e o estabelecido, entre o selvagem e o ordenado, em suma, entre ruído e som, tem correspondido, desde o entreguerras do século XX, ao desenvolvimento da juventude como um ator social diferenciado e como segmento de um público consumidor específico. Por sua vez, a tensão entre esses dois lugares sociais, o protagonismo juvenil e o consumo, sinaliza à sociedade as práticas que, no presente, lhe abrem possíveis futuros. Continuando uma tradição ou inaugurando outra, as manifestações artísticas sempre interceptam valores que operam na instituição imaginária da sociedade, valores muitas vezes estratégicos para a aceitação, o reconhecimento e a legitimação por parte dos jovens. Cabe à educação escutálos com atenção, inclusive para poder problematizá-los de maneira conseqüente, desarmando as armadilhas do preconceito. A crise na educação não deixa de ser uma das formas do atual mal-estar na cultura. Enfrentá-los é redimensionar o presente sentido da formação, é atualizar o insubstituível valor educativo de propor formas de decantar, de traduzir, de conversar e de elaborar a experiência do nosso tempo.

\section{NOTAS}

${ }^{1}$ Sobre esse tema, há muitos trabalhos de antropologia urbana e sociologia da juventude. Para citar apenas alguns que contribuem para mapear a questão no Brasil, ver Magnani (2005); Abramo (2005); Sposito (2005, 1994); Dayrell (2002).

${ }^{2}$ Os próprios Parâmetros Curriculares Nacionais e, mais recentemente, as novas Orientações Curriculares Nacionais para o ensino das linguagens das artes plásticas, da música e da literatura falam diretamente em "educação da sensibilidade" e na consideração crítica da cultura vivida e imediata do aluno, embora em perspectiva eclética e muitas vezes confusa. O interessante é que a crise da forma escolar tem forçado até mesmo o discurso oficial a procurar combinar o acento que as pedagogias tradicionais conferiam aos conteúdos humanistas com as perspectivas críticas das pedagogias pragmáticas, construtivistas e não-diretivas que, desde os anos 1920, procuram assegurar uma formação centrada na produção da autonomia do aluno e de um sentido democrático às práticas escolares. Cabe notar, porém, que nem os PCN's, nem os PCNEM's dedicados à música e à literatura fazem qualquer destaque à linguagem da canção e de sua importância no Brasil (BRASIL, 2005; 2007).

${ }^{3}$ Isso é, evidentemente, uma generalização, talvez um pouco etnocêntrica, pois é possível analisar a vitalidade e a organicidade da canção popular urbana como vetor de um atual (pós-) modernismo cultural em toda a América Latina, em grande parte da Europa e mesmo da Rússia e do Japão, notadamente as canções "tipicamente locais e universais" 
de Cuba (em ritmo de son, salsa ou rap), da Jamaica (do reggae às inúmeras variações de dubb eletrônico, uma "febre" nas raves contemporâneas), da França (no inegável estilo discursivo da chançon française, atualizado em raps e pops inovadores) e da Argentina (com o tango, ritmo e estilo que, tal como o samba, já nasceu de fusões de sonoridades urbanas rapidamente difundidas pelo mundo todo).

4 A questão do hibridismo da canção é de fundamental importância para pensá-la como índice da modernidade cultural brasileira e, mais do que isso, para conectá-la a uma reflexão sobre a modernidade cultural latino-americana. Ao rever a literatura crítica a respeito desse tema, Néstor Garcia Canclini nomeou o problema da relação entre arcaico e moderno nas linguagens artísticas e nas práticas culturais latino-americanas como a especificidade de "culturas híbridas", isto é, nem "autônomas", "autóctones" e "puras", nem meramente importadas ou transplantadas da realidade européia (que as colonizou). Nesse sentido, os processos de "hibridação" se tornam a maneira específica de as formações latino-americanas se modernizarem de modo a não se converterem puramente "no moderno", mas sem deixar de nele se situarem e atualizarem constantemente. Daí Canclini propor como título de seu estudo "Culturas híbridas: estratégias para entrar e sair da modernidade" (CANCLINI, 2003, p. XIX). No Brasil, em outros termos, esse pensamento remonta ao Modernismo dos anos 1920-30, sobretudo à antropofagia de Oswald de Andrade, que propunha a devoração e a incorporação do estrangeiro como processo constitutivo das linguagens artístico-culturais. Sobre o tema e como ele foi retomado na música tropicalista, ver Favaretto (2000a).

${ }^{5}$ As formas de consumo, no entanto, variam enormemente e, com elas, seus significados (CANCLINI, 2006).

${ }^{6}$ A terminologia esquemática é de um executivo de uma grande gravadora que assim rotula as músicas para subdividir seus produtos (Apud GARCIA, 2004, p. 167).

${ }^{7}$ Vianna (2002) mostra como se deu a invenção ou a construção social do samba como "gênero nacional", num momento em que, política e ideologicamente, a moderna acepção da identidade nacional brasileira também era social e culturalmente inventada, sobretudo por obra das instituições políticas públicas e autoritárias da Era Vargas. Já Tatit (2004, p. 143175) evidencia como o samba partia da formalização estética de um modo de dizer de cuja matriz saiu um "prumo para a composição de canções que até hoje serve de referência aos artistas de maior apuro técnico", como a bossa de João Gilberto. Da seresta, passando pelo samba-canção às marchinhas de carnaval, há variações de acelerações ou desacelerações do "samba-samba". Este, portanto, garantiu que "a base é uma só”, conseguindo estabilizar melodicamente, com eficiência e naturalidade, a entoação temática de nossa língua como nenhum outro ritmo da música brasileira.

${ }^{8}$ Afirma o historiador: "diferente trajetória teve o samba que podemos chamar de paulistano, pois este não conseguiu assegurar seu espaço de produção e difusão no universo urbano e, sobretudo, nos meios de comunicação em emergência. De maneira geral, as rádios e gravadoras de São Paulo negligenciaram os compositores e instrumentistas do samba paulistano". Ao contrário do que se deu com o samba carioca, que herda o batuque e a ginga baiana, encontra um molejo novo para o corpo, sedimenta um sotaque, inventa a figura do malandro e fala às diferentes temporalidades da antiga capital da república, "a lógica da tradição transformada e móvel [do modo de vida do planalto] não teve condições de realizar-se no universo do samba regional paulista(no)". (MORAES, 2000, p. 288) 
${ }^{9}$ Alude-se, aqui, aos conceitos de Erfarung (Experiência) e Erlebnis (Vivência), de Walter Benjamin (1996a; 1996b).

${ }^{10} \mathrm{Na}$ era da globalização e das refuncionalizações do território trazidas com novos meios técnico-científicos e econômicos, as assim chamadas "cidades globais" não se caracterizam por uma formação urbana "homogênea" (induzida pela idéia de cidade), mas por uma "dispersão concentrada" de atividades ultra-sofisticadas. Cf. (SASSEN, 1998). Sobre a caracterização das cidades globais e a discussão das abordagens crítica e apologética do urbanismo que as acompanha no Brasil, ver Fix (2007).

${ }^{11}$ Título do livro de poemas sobre a São Paulo dos anos 1920, de Mário de Andrade (2005).

${ }^{12}$ Como afirma Wisnik, autor-chave para a compreensão do aspecto pulsional profundo da música, esta "não refere nem nomeia coisas visíveis, como a linguagem verbal faz, mas aponta com uma força toda sua para o não-verbalizável; atravessa certas redes defensivas que a consciência e a linguagem cristalizada opõem à sua ação e toca em pontos de ligação efetivos do mental e do corporal, do intelectual e do afetivo. Por isso mesmo é capaz de provocar as mais apaixonadas adesões e as mais violentas recusas" (WISNIK, 2002, p. 28). ${ }^{13}$ Trata-se de uma interlocução indireta com a clássica obra $A$ reprodução, de Bourdieu e Passeron (1975), em que os autores enfatizavam a escola como uma instituição conservadora e um lugar de reprodução sociológica de discursos, de relações de dominação e de produção da sociedade, minimizando, portanto, os espaços de liberdade e as especificidades próprias da instituição escolar.

${ }^{14} \mathrm{O}$ único equipamento público que se tornou universalmente oferecido às crianças e aos adolescentes de nossas cidades é a escola. Segundo dados do MEC, em 2002, 96,5\% das crianças em idade escolar obrigatória (dos sete aos 14 anos) estavam matriculadas no sistema de ensino. Isso quer dizer que, mal ou bem, a escola tornou-se um equipamento social que efetivamente penetra o território brasileiro. Em pouco mais de 20 anos, o processo de democratização do acesso ao ensino deu largas passadas (basta conferir, em qualquer família brasileira média, os graus de instrução nas últimas três gerações). Por um lado, essa realidade se deve a sucessivas políticas de estado, notadamente aquelas do desenvolvimentismo militar - nas quais deslancharam também acordos com órgãos internacionais (como o BID e o Bird) e incentivos à rede privada de ensino. Por outro lado, através da pedagogia da política, os movimentos sociais forçaram a política da pe--dagogia a abrir o ensino público a toda a população. Da escola aristocrática, que oferecia muito saber a poucos, passamos à hegemonia da escola contábil, que oferece pouco saber a muitos. Nisso, porém, os movimentos sociais afirmam seu direito à cidade e, com isso, forçam a negação da apropriação privada (elitista) de escolas, do saber e das infra-estruturas urbanas necessárias à sua socialização, Cf. Sposito (1992); Mommeny (2001); Andrade (2002).

${ }^{15}$ Cf. Zaluar (2000). No mesmo sentido, mas de um ponto de vista habermasiano, Maria Célia Paoli sustenta que, no Brasil, a canção popular urbana teria cumprido o "trabalho simbólico e imaginário de construir um referencial de interpretação da vida privada popular, coisa que, nas sociedades onde a modernidade se originou, foi tarefa da literatura moderna" (PAOLI, 2004, p. 74).

${ }^{16}$ Nessa direção, as pesquisas de sociologia da juventude e sociologia da educação de Abramo (1994) e Dayrell (2001) são exemplares.

${ }^{17}$ Nesse sentido, Maria Rita Kehl enxerga comportamentos aparentemente "anômalos" de certos jovens de classe média como sintomas reveladores de uma inversão geral entre os 
papéis jovens e adultos na cultura, uma crise de autoridade derivada de uma "teenagerização" da cultura ocidental. Um ponto interessante da análise de Kehl diz respeito à identificação de jovens brancos e ricos com os manos pobres e negros da cultura hip hop. Se, por um lado, a identificação se deve à sedução de poder exercida pela violência e pela lógica do espetáculo que perpassa os meios de comunicação, por outro lado, há nessa identificação uma "malandragem adolescente", que, por sua vez, responde a uma "malandragem adulta". "Os pais das famílias de classe média temem as más influências dos 'maloqueiros' do bairro sobre seus filhos, mas não percebem que os priores exemplos de irresponsabilidade e de falta de educação provêm da própria elite nacional, acostumada a conviver com uma série de práticas ilegais, de maior ou menor gravidade. (...) A convivência com a criminalidade dos marginais e dos miseráveis acovarda e corrompe os adolescentes, principalmente quando estes perdem a confiança na Justiça e na polícia que deveria proteger a sociedade toda. Mas a convivência com o cinismo e com a ilegalidade das práticas da elite corrompe e educa para o crime boa parte das novas gerações, de maneira muito mais profunda e eficiente" (KEHL, 2004, p. 104-105).

\section{REFERÊNCIAS}

ABRAMO, H.W. Condição juvenil no Brasil contemporâneo. In: ABRAMO, H.W.; BRANCO, P.P.M. (Orgs.). Retratos da juventude brasileira: análises de uma pesquisa nacional. São Paulo: Instituto Cidadania/Editora Fundação Perseu Abramo, 2005.

ANDRADE, J.P. Cidade Cantada: experiência estética e educação. 2007, 200f. Dissertação (Mestrado), Faculdade de Educação da Universidade de São Paulo, São Paulo, 2007.

ANDRADE, J.P. Pedagogias da cidade: a escola e seu entorno. Correio da Cidadania, São Paulo, edição 304, jul. de 2002.

ANDRADE, M. Paulicéia desvairada. In: ANDRADE, M. Poesias Completas. São Paulo: Itatiaia, 2005.

ARENDT, H. A crise na educação. In: ARENDT, H. Entre o passado e o futuro. São Paulo: Perspectiva, 2000.

BAIA, Silvano. A Pesquisa sobre Música popular no estado de São Paulo (Brasil): o estado da arte. Buenos Aires: Anais del IV Congreso Latinoamericano LASPM-AL, 2005. Disponível em: <http://www.hist.puc.cl/historia/iaspm/actasbaires.html>. Acesso em 03/07/2006.

BARTHES, R. O Grão da Voz. In: BARTHES, R. O Óbvio e o Obtuso. Ensaios críticos III. 3 ed. São Paulo: Nova Fronteira, 2004.

BENJAMIN, W. Experiência e Pobreza. In: BENJAMIN, W. Obras Escolhidas I - Magia e Técnica, arte e política. São Paulo: Brasiliense, 1996a.

BENJAMIN, W. O Narrador. Considerações sobre a obra de Nicolai Leskov. In: BENJAMIN, W. Obras Escolbidas I- Magia e Técnica, arte e política. São Paulo: Brasiliense, 1996b. BENJAMIN, W. Sobre o Conceito de História. In: BENJAMIN, W. Obras Escolbidas I Magia e Técnica, arte e política. São Paulo: Brasiliense, 1996c.

BOMENY, H. Os intelectuais da educação. Rio de Janeiro: Jorge Zahar, 2001 (Coleção Descobrindo o Brasil).

BOURDIEU, P.; PASSERON, J.C. A reprodução: elementos para uma teoria do sistema de ensino. Rio de Janeiro: Francisco Alves, 1975.

BRASIL. Orientações Curriculares para o Ensino Médio PCNEM. Vol. 1. Linguagem, código e suas tecnologias. Secretaria de Educação Fundamental. Brasília: MEC/SEF, 2006/2007. Disponível em: http://portal.mec.gov.br/seb/arquivos/pdf/book_vo- 
lume_01_internet.pdf. Acesso em 07/08/2007.

BRASIL. Parâmetros Curriculares Nacionais para a Educação Básica. Secretaria de Educação

Fundamental. Brasília: MEC/SEF, 1997. Disponível em: $<$ http://portal.mec.gov.br/seb/arquivos/pdf>. Acesso em 10/02/2005.

CALDEIRA, T.P.R. Cidade de Muros: crime, segregação e cidadania em São Paulo. São Paulo: Edusp/Editora 34, 2000.

CANCLINI. N. G. Consumidores e Cidadãos. 6 ed. Rio de Janeiro: Editora UFRJ, 2006.

CANCLINI. N. G. Culturas Híbridas: estratégias para entrar e sair da modernidade. 4 ed. São Paulo: Edusp, 2003.

CAMPOS, A. O Balanço da Bossa e outras Bossas. 5 ed. São Paulo: Perspectiva, 2005.

COSTA, J.F. Perspectivas da juventude na sociedade de mercado. In: NOVAES, R.; VANNUCHI, P. (Orgs.). Juventude e sociedade: trabalho, educação, cultura e participação. São Paulo: Instituto Cidadania/Editora Fundação Perseu Abramo, 2004.

DAYRELL, J. O rap e o funk na socialização da juventude. Educação e Pesquisa. Revista da Faculdade de Educação da USP, v. 28, n. 1, p. 117-136. São Paulo, FEUSP, 2002.

DE CERTEAU, M. As universidades diante da cultura de massa. In: DE CERTEAU, M. A Cultura No Plural. 4 ed. São Paulo: Papirus, 2005.

ECO, U. A canção de consumo. In: ECO, U. Apocalípticos e Integrados. 6 ed. São Paulo: Perspectiva, 1979.

FAVARETTO, C. A Invenção de Hélio Oiticica. 2 ed. São Paulo: Edusp, 2000a.

FAVARETTO, C. Tropicália: alegoria, alegria. 3 ed. São Paulo: Ateliê Editorial, 2000b.

FIX, M. São Paulo cidade global: fundamentos de uma miragem financeira. São Paulo: Boitempo, 2007.

GARCIA, W. Ouvindo Racionais MC's. TERESA, Literatura e Canção - Revista de Literatura Brasileira, n. 4/5, p. 167-180. São Paulo: Editora 34, 2004.

GARCIA, W. Bim Bom. A contradição sem conflito de João Gilberto. São Paulo: Paz e Terra, 1999.

KEHL, M.R. A juventude como sintoma da cultura. In: NOVAES, R.; VANNUCHI, P. (Orgs.). Juventude e sociedade: trabalho, educação, cultura e participação. São Paulo, Instituto Cidadania/Editora Fundação Perseu Abramo, 2004.

MAGNANI, J.G. Circuitos juvenis paulistanos. Tempo Social. Revista de Sociologia da USP, v.17, n. 2, p. 173-205, São Paulo, FFFLCH/USP, 2005.

MAMMÍ, L. Erudito/Popular. In: PAIVA, M.; MOREIRA, M. E. (Orgs.). Cultura. Substantivo Plural. Rio de Janeiro: Editora 34, 1996.

MORAES, J.G.V. Metrópole em Sinfonia. História, Cultura e Música Popular na São Paulo dos anos 30. São Paulo, Estação Liberdade/FAPESP, 2000.

MORIN, E. Não se conhece a canção. In: MORIN, E. Linguagem da cultura de massas. Petrópolis: Vozes, 1973.

PAOLI, M.C. Os amores citadinos e a ordenação do mundo pária: as mulheres, as canções e seus poetas. In: CAVALCANTI, B.; STARLING, H.; EISENBERG, J. (Orgs.). Decantando a República: Inventário histórico e político da canção popular moderna brasileira. Vol. III. São Paulo/Rio de Janeiro: Nova Fronteira/ Fundação Perseu Abramo, 2004.

RODRIGUES, A.M. A Poesia Lírica das Modinhas e a Solidão Política. Jornal da Tarde, São Paulo, 26 julho, 1980.

SASSEN, S. As cidades na economia mundial. São Paulo: Studio Nobel, 1998.

SANTOS, M. Por uma Economia Política da Cidade. São Paulo: Hucitec/EDUC, 1994. 
SANTOS, M. Metrópole corporativa fragmentada: o caso de São Paulo. São Paulo: Nobel/Secretaria de Estado da Cultura, 1990.

SCHWARZ, R. Fim de século. In: SCHWARZ, R. Seqüencias Brasileiras. São Paulo: Companhia das Letras, 1999.

SPOSITO, M.P. Algumas Reflexões e muitas indagações sobre as relações entre juventude e escola no Brasil. In: ABRAMO, H.W.; BRANCO, P.P.M. (Orgs.). Retratos da Juventude Brasileira: análises de uma pesquisa nacional. São Paulo: Instituto Cidadania/Editora Fundação Perseu Abramo, 2005.

SPOSITO, M.P. A Sociabilidade Juvenil e a rua: novos conflitos e ação coletiva na cidade. Tempo Social, Revista de Sociologia da USP, v. 5, n. 1-2, p. 161-178. São Paulo, FFFLCHUSP, nov. 1994.

SPOSITO, M.P. O povo vai à escola: a luta popular pela expansão do ensino público em São Paulo. São Paulo: Edições Loyola, 1992.

VIANNA, H. O Mistério do Samba. 4 ed. Rio de Janeiro: Jorge Zahar/UFRJ, 2002.

TATIT, L. O século da canção. São Paulo: Ateliê Editorial, 2004.

TERESA: Literatura e Canção - Revista de Literatura Brasileira, n. 4/5. São Paulo: Editora 34, 2004.

TOLEDO, R.P. A Capital da Solidão: uma história de São Paulo das origens a 1900. São Paulo: Objetiva, 2004.

WISNIK, J.M. O Minuto e o Milênio ou Por favor, Professor, Uma Década de Cada Vez. In: WISNIK, J.M. Sem Receita: ensaios e canções. São Paulo: Publifolha, 2004a.

WISNIK, J.M. A Gaia Ciência. Literatura e Música Popular no Brasil. In: WISNIK, J.M. Sem Receita: ensaios e canções. São Paulo: Publifolha, 2004b.

WISNIK, J.M. Te-Manduco-Não-Manduca: a música popular de São Paulo. In: WISNIK, J.M. Sem Receita: ensaios e canções. São Paulo: Publifolha, 2004c.

WISNIK, J.M. O som e o sentido: uma outra história das músicas. São Paulo: Companhia das Letras, 2002.

WISNIK, J.M. Getúlio da Paixão Cearense. In: SQUEFF, E.; WISNIK, J. M. O Nacional e o Popular na Cultura Brasileira. Música. 2 ed. São Paulo: Brasiliense, 1983.

ZALUAR, A. Para não dizer que não falei de samba: os enigmas da violência no Brasil. In: ZALUAR, A. História da vida privada no Brasil, Vol. III. Contrastes da intimidade contemporânea. São Paulo: Companhia das Letras, 2000.

ZÉ, T. Tropicalista: lenta luta. São Paulo: Publifolha, 2003.

ZUMTHOR, P. A poesia e o corpo. In: ZUMTHOR, P. Escritura e Nomadismo. São Paulo: Ateliê Editorial, 2001.

Recebido: $10 / 06 / 08$

Aprovado: $12 / 12 / 08$

Contato:

Rua Benito Juzrez, 81

Vila Mariana

São Paulo - SP

04018-060 